\title{
PERIGLAGIAL FEATURES ON THE MARGINS OF A RECEDING PLATEAU ICE CAP, LYNGEN, NORTH NORWAY
}

\author{
By W. Brian Whalley, \\ (Department of Geography, Queen's University of Belfast, Belfast BT 7 INN, U.K.) \\ JoHn E. Gordon, \\ (Nature Conservancy Council, Pearl House, Reading, Berkshire RGi4 5LS, U.K.) \\ and David L. Thompson \\ (Springhead School, Northfleet, Kent, U.K.)
}

\begin{abstract}
Some features around the perimeter of the Balgesvarri plateau ice cap are described. Sorted stone circles were found beneath a slowly retreating ice margin, the basal ice in this area appears to be below the pressure-melting point. No absolute dating of features was possible but a relative chronology is suggested.

RÉsumé. Le retrait glaciaire et les manifestations périglaciaires sur les marges d'un glacier de calotte à Lyngen, Norvège du nord. On décrit quelques traits caractéristiques du pourtour du glacier de calotte de Balgesvarri. Des sols polygonaux ont été découverts à l'aval d'un front glaciaire en léger retrait. La glace de fond dans cette zone semble être en dessous du point de fusion correspondant à la pression. Il n'a pas été possible d'établir une datation absolue de ces manifestations périglaciaires mais on propose une chronologie relative.

Zusammenfassung. Gletscherrückgang und periglaziale Erscheinungen an den Rändern einer Plateau-Eiskappe, Lyngen, Nordnorwegen. Einige Erscheinungen an der Peripherie der Balgesvarri-Plateaukappe werden beschrieben. Unter einem langsam zurückgehenden Eisrand wurden Steinkreise gefunden; das Eis am Untergrund dieser Region dürfte sich unter dem Druckschmelzpunkt befinden. Eine absolute Datierung der Erscheinungen war nicht möglich, doch lässt sich eine relative zeitliche Abfolge ermitteln.
\end{abstract}

\section{INTRODUCTION}

In 1979 the British Schools Exploring Society undertook a glaciological reconnaissance of two small plateau ice caps on the Lyngen peninsula, Troms, north Norway (lat. $69^{\circ} 25^{\prime}$ N., long. $19^{\circ} 52^{\prime}$ E.). The higher one, Balgesvarri (c. I $622 \mathrm{~m}$ ), is an ice dome $c .0 .7 \mathrm{~km}^{2}$ in area sitting on top of a plateau remnant formed in gabbro bedrock and lies in basin 816 in the glacier atlas of northern Scandinavia (Østrem and others, 1973). This note presents some preliminary findings, related in particular to periglacial features in the narrow zone of ice-free ground or "promenade" which extends discontinuously between the ice and the precipitous cliffs delimiting the plateau edge (Fig. I).

Balgesvarri is the lowest of the four main plateau-top glaciers in southern Lyngen (the others are: Jiekkevarri I $833 \mathrm{~m}$, Kveita $c$. I $720 \mathrm{~m}$, and Fugledalsfjell $c$. I $710 \mathrm{~m}$ ) but it is the easiest of access. Although no soundings through the ice were taken, interpolated survey measurements across the plateau suggest a maximum ice thickness of about $60 \mathrm{~m}$. For the most part the ice margin descends at angles between $10-30^{\circ}$ to the felsenmeer of the plateau, but at four places ice falls cascade over the lip as small hanging glaciers (Fig. I). Basic topographic conditions are similar for the other ice caps although the ice-free "promenades" around the glacier perimeters are usually less extensive. Beyond the basic catalogue of ice masses in the atlas of glaciers in northern Scandinavia (Østrem and others, 1973) nothing is known about the glaciology or geomorphology of these small ice caps and their response to climatic changes. However, our observations of the ice at the edge of Balgesvarri and the periglacial features on the rock debris of the felsenmeer provide some clues about its recent behaviour.

\section{THE PRESENT-DAY ICE RETREAT}

On some of the areas of the Balgesvarri felsenmeer the thickness of the rock debris is estimated to be at least $1.5 \mathrm{~m}$ and has been proved to $0.5 \mathrm{~m}$ by digging. Intuitively, a long period of time would seem to be required for this thickness to form, although no measurements on rock breakdown have been made (in Norway or elsewhere) which could be used to estimate this time.

At some places on the plateau there is a distinct colour difference between weathered rock outcrops and felsenmeer, and a band of lighter-coloured boulders (Fig. 2). The lighter rocks have hardly any 


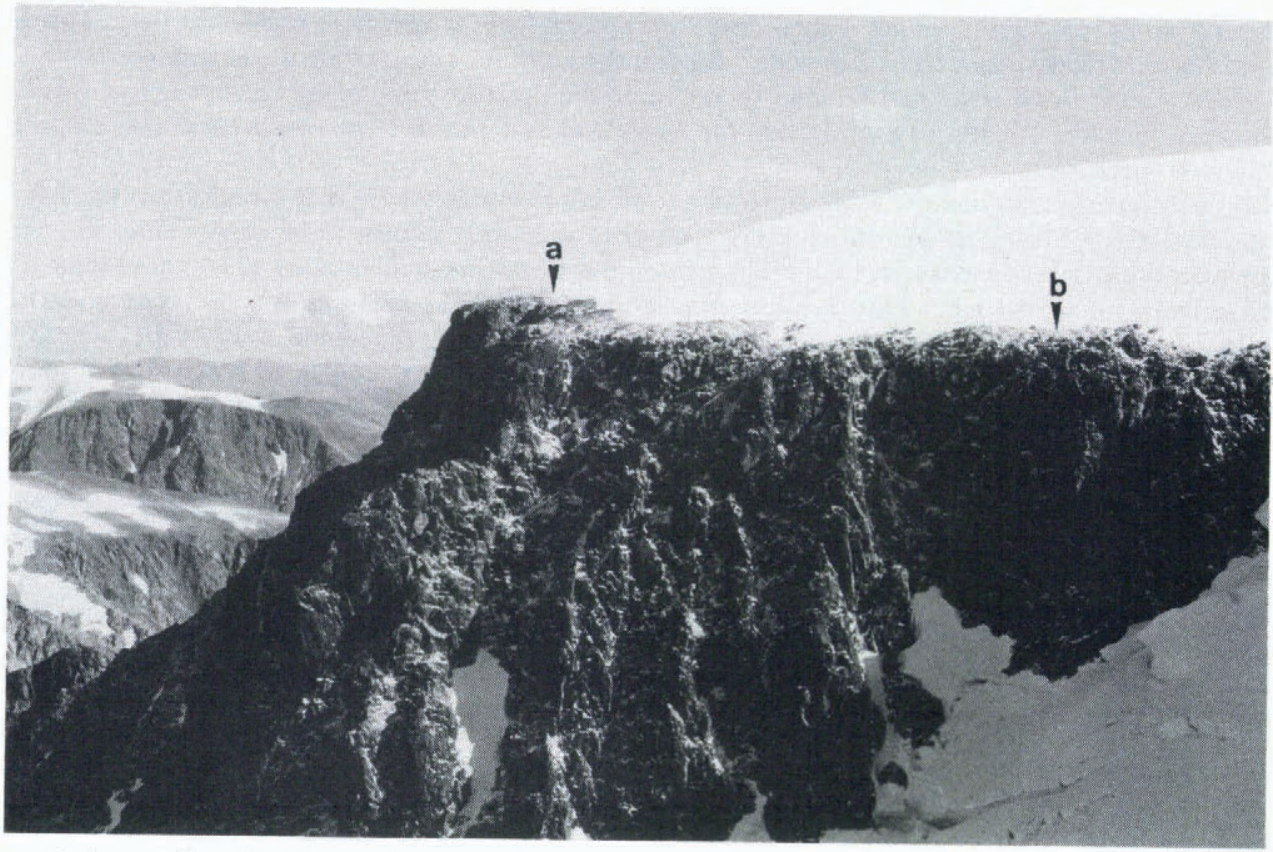

Fig. I. A view east from the Balgesvarri plateau edge showing the "promenade" and the area of the stone circles (a) and ice slot (b) described. One of the hanging glaciers descending from the ice cap is visible lower right.

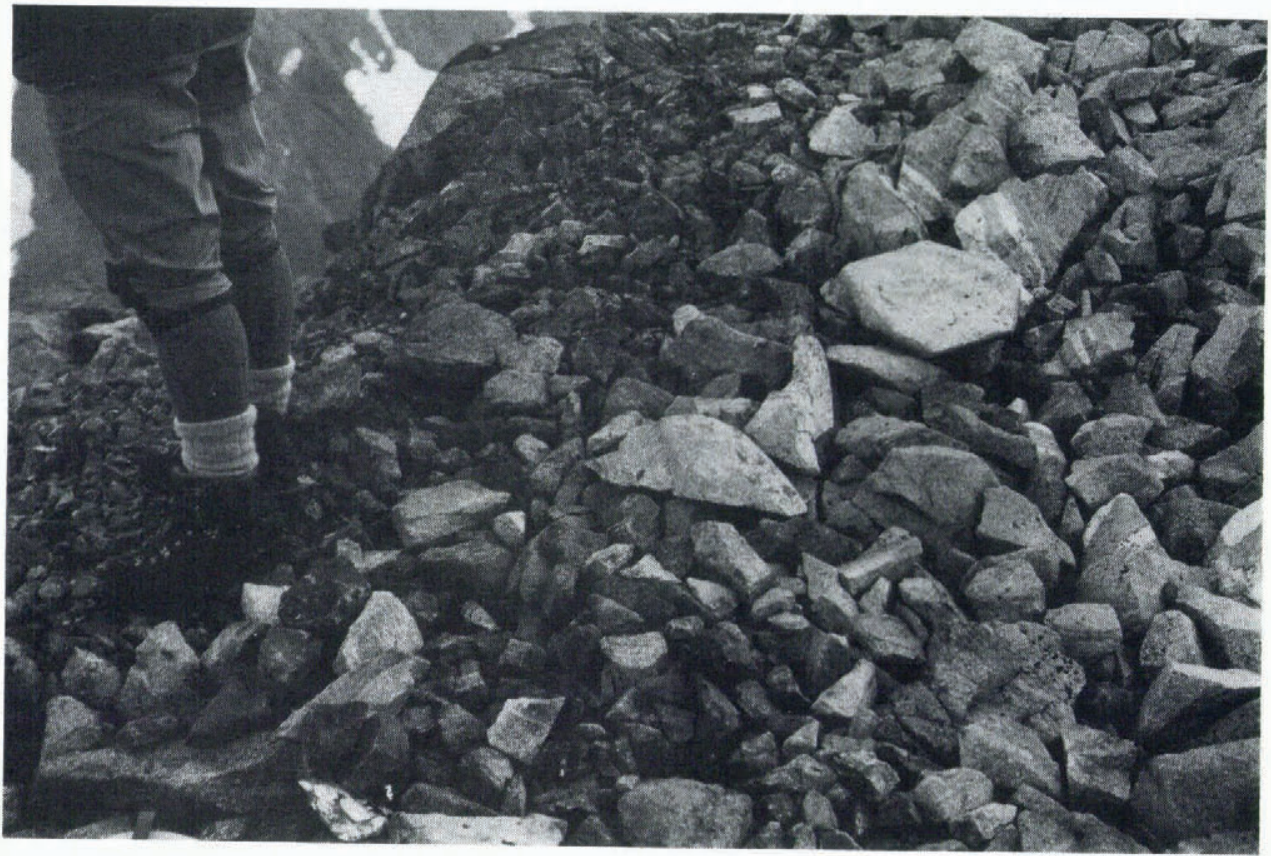

Fig. 2. Plateau edge on the south of the cap showing the clear colour difference between the well-weathered and recently revealed
felsenmeer. 
weathering rinds, are very sparsely lichen covered, and appear to continue under the ice. This lightcoloured band is rarely more than $2 \mathrm{~m}$ wide. Again, there are no growth-rate measurements in the area from which lichen thalli sizes can be used to estimate the possible time of ice retreat across this band. The measurements of Karlén (1973) are too far away and in a much more continental climate to be of value in this instance.

The "promenade" does show some areas of sorted stone circles where rock breakdown has left fines near the surface. Often these are surprisingly well developed and appear to be active (Fig. 3). On the light-coloured band on the eastern edge of the plateau, the melting glacier margin revealed some circles emerging from under the ice. This phenomenon is apparently rare and has only been described from rather low-lying areas in Canada (Falconer, I966) and Antarctica (Black and Berg, 1964) where large tundra polygons and ice-sheet remnants are involved. We have been unable to trace reports of sorted stone circles from mountain tops with retreating ice masses. As such circles were also found (at about I $400 \mathrm{~m}$ ) it is likely that other examples exist in the area.

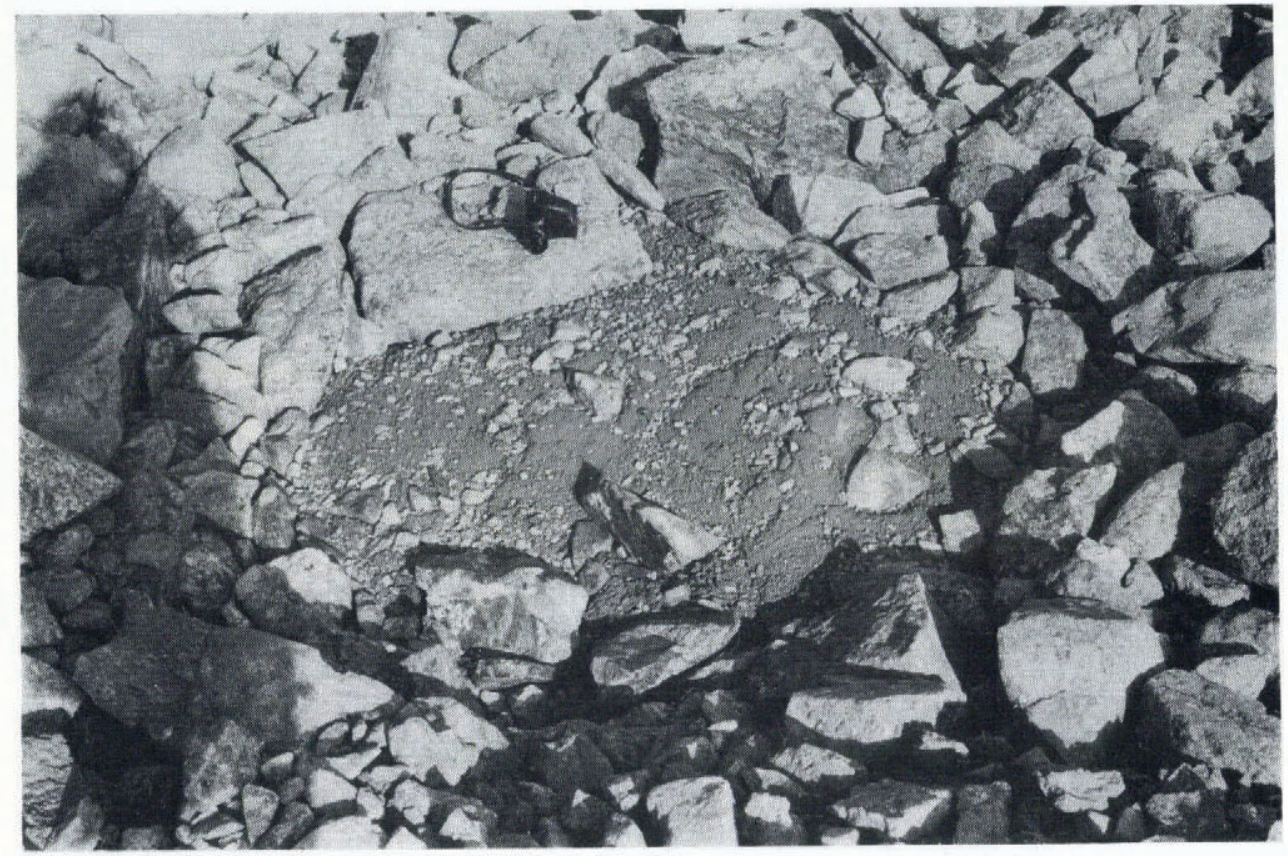

Fig. 3. A well-formed, sorted stone circle in the well-weathered part of the felsenmeer.

One further point of interest, again not recorded in the literature, concerns the slope of these polygons. Several examples in the area indicated in Figure $\mathrm{I}$ have a tilt towards the ice and not, as might be expected, away from the ice and down-slope towards the plateau edge (Fig. 4).

The most obvious explanation for this tilting is that loading by the ice has caused deformation in the mass of the felsenmeer in a way similar to the failure of an embankment toe by plastic deformation (e.g. Smith, 1978). It is not known whether the deformation took place in fines below the surface (perhaps water-saturated) or in frozen material in a similar fashion to the deformation of "push moraines" discussed by Kälin (197I).

It is possible to suggest a sequence of events which takes account of the findings presented and thereby help elucidate the climatic response of the glacier in the absence of other suitable data from the area. It would seem unlikely, and there have been no suggestions in the literature, that sorted stone circles can form under ice. Therefore the ice cap must now be retreating from previously formed features. The tilting of the circles indicates the growth and advance of the ice onto this area, possibly with a long period sitting near the plateau edge. Examination of the degree of bedrock weathering does not suggest that ice spilled over the edge of the plateau in this region in the recent past. The simplest 


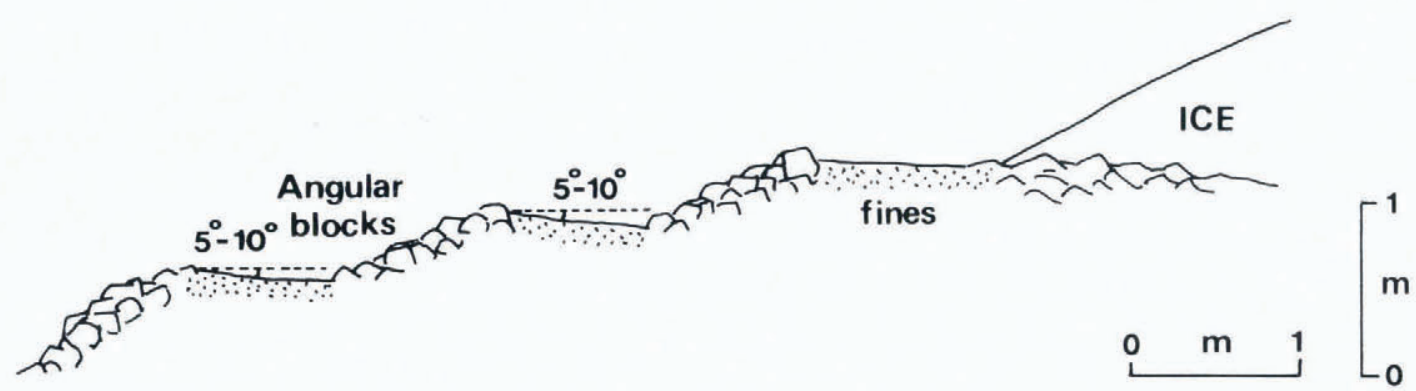

Fig. 4. Sketch cross-profile of the emergent and backwards-tilting stone circles at the site shown in Figure I.

conclusion is that the ice cap grew and overran circles which had formed already under periglacial conditions at its perimeter, causing deformation at some stage. Only in recent years has the ice retreated sufficiently to reveal these features. Snow density and thickness studies in a $4 \mathrm{~m}$ deep pit on the plateau summit suggest a relatively stable, only slightly decreasing accumulation rate, which is in favour of a scarcely retreating margin. The narrowness of the unweathered light band also supports this view.

It is possible to ascribe dates to these events only with reference to the generally accepted dating of glacial sequences in Scandinavia. Few dates exist for glacial events in the Lyngen area. Various reports of expeditions to the area record a succession of retreat moraines in front of glaciers and Whalley (I973) has shown that a large valley glacier $20 \mathrm{~km}$ to the north has been in retreat since at least the turn of the century. In general, it would appear that ice is retreating from a Neuzeitlich (= little ice age $c$. A.D. I 750-1900) glacier extension. The dates for this vary according to author, Andersen (I968) in western Troms suggested an eighteenth-century advance although Karlén (r973) working in Kebnekaise some $200 \mathrm{~km}$ to the south-west (but in an area of more continental climate) believes the first advances may be from the beginning of the sixteenth century. The sorted circles would have formed at some stage before this period of advance and the production of the felsenmeer well before then. Present-day conditions are suitable for the formation of stone circles, and therefore the pre-Neuzeitlich warm period (= medieval warm period or little optimum, Lamb, 1977) would have been the earliest time that the presently exposed circles could have formed.

One further surprising aspect of the Balgesvarri ice cap was found during the cutting of a slot into the ice on the northern aspect (Fig. I). The ice proved to be particularly tough and large grained $\left(2-3 \mathrm{~cm}\right.$ being common) with banding dipping down-glacier at $20-22^{\circ}$, the surface slope being $25^{\circ}$. The ice-bed contact showed an irregular surface of stones with a slightly raised edge of $15-20 \mathrm{~cm}$ above the general level some $1.5 \mathrm{~m}$ from the ice edge. This could indicate a certain amount of pushing by advancing ice. However, the apparent lack of lateral distortion or smearing of the revealed stone circles gives reason to believe that the glacier overriding was essentially passive. One stone, $4.6 \mathrm{~m}$ from the edge has a small piece of lichen (species not identified) still attached. A band of dust in the ice contained some pollen (Scots pine and Norway spruce) but not sufficient for an environmental appraisal. The ice-substratum contact in the slot was found to be frozen although cold base conditions had not been expected. Thermistors have been left in a summit snow pit to obtain $10 \mathrm{~m}$ temperatures and velocity stakes inserted in order to give a better idea of the thermal and dynamic regime of the ice mass and confirm the extent of the frozen bed. The other high ice caps would also be expected to have sub-zero basal temperatures although the lower plateau investigated at Bredalsfjell has a rapidly retreating ice mass which does not have ice frozen to the bed. An altitude between I 600 and I $500 \mathrm{~m}$ therefore appears critical for the maintenance of a frozen-bed glacier in this region.

\section{Conclusions}

The high plateau ice caps of south Lyngen, exemplified by Balgesvarri, are worthy of further, detailed study as they can cast light on the late glacial and deglacial history of northern, maritime Troms. Furthermore, they could be analogous to the high plateaux of Scotland when the latter had ice caps some Io 000-I I ooo a B.P. If this analogy holds, they could provide valuable models for elucidating the thermal regime and dynamics of the Scottish glaciers. 


\section{AcKNowledgements}

We thank the members and sponsors of the 1979 British Schools Exploring Society Expedition, in particular, those who helped in the ice and snow digging and who provided logistical support. Dr K. Edwards kindly identified the pollen grains.

$M S$. received 23 June 1980 and in revised form 3 October 1980

\section{REFERENCES}

Andersen, B. G. 1968. Glacial geology of western Troms, north Norway. Norges Geologiske Undersøkelse, No. 256. Black, R. F., and Berg, T. E. I964. Glacier fluctuations recorded by patterned ground, Victoria Land. (In Adie, R. J., ed. Antarctic geology: proceedings of the first international symposium on Antarctic geology, Cape Town, 16-2I September 1963. Amsterdam, North-Holland Publishing Co., p. ro7-22.)

Falconer, G. 1966. Preservation of vegetation and patterned ground under a thin ice body in northern Baffin Island, N.W.T. Geographical Bulletin (Ottawa), Vol. 8, No. 2, p. 194-200.

Kälin, M. 1971. Glaciology, No. 4. The active push moraine of the Thompson Glacier, Axel Heiberg Island, Canadian Arctic Archipelago. Axel Heiberg Island Research Reports, McGill University, Montreal.

Karlén, W. 1973. Holocene glacier and climatic variations, Kebnekaise mountains, Swedish Lapland. Geografiska Annaler, Vol. 55A, No. I, p. 29-63.

Lamb, H. H. I977. Climate, present, past, and future. Vol. 2. Climatic history and the future. London, Methuen.

Østrem, G., and others. 1973. Atlas over breer i Nord-Skandinavia: Glacier atlas of northern Scandinavia, [by] G. Østrem, N. Haakensen, O. Melander. Norges Vassdrags- og Elektrisitetsvesen. Meddelelse fra Hydrologisk Avdeling, Nr. 22 ; Stockholms Universitet. Meddelande från Naturgeografiska Institutionen, Nr. 46.

Smith, G. N. 1978. Elements of soil mechanics for civil and mining engineers. Fourth edition. London, Crosby Lockwood

Staples.
Whalley, W. B. 1973. A note on the fluctuations of the level and size of Strupvatnet, Lyngen, Troms, and the interpretation of ice loss on Strupbreen. Norsk Geografisk Tidsskrift, Bd. 27, Ht. I, p. 39-45. 